\title{
Analysis of Market Trends Within the Romanian Silk Industry
}

\author{
Lucia Lelia POP ${ }^{1}$, Liviu Alexandru MĂRGHITAȘ ${ }^{1}$, Otilia BOBIȘ ${ }^{2}$, Adela Ramona MOISE ${ }^{1}$ and Daniel \\ Severus DEZMIREAN ${ }^{1}$ \\ ${ }^{1}$ University of Agricultural Sciences and Veterinary Medicine, Calea Manastur, Cluj Napoca, Romania \\ ${ }^{2}$ Life Sciences Institute Mihai the First, King of Romania, Calea Manastur, Cluj Napoca, Romania \\ *Ccorresponding author: Iucia.lelia.pop@gmail.com
}

Bulletin UASVM Animal Science and Biotechnologies 77(1)/ 2020

Print ISSN 1843-5262; Electronic ISSN 1843-536X

DOI:10.15835/buasvmcn-asb: 0024.19

\begin{abstract}
According to the scientific literature, sericulture is the science with its focus on the silkworm rearing process, as well as the processing of silk and silk derived products. As a rural economic activity, sericulture is being usually, at small scale, being given a cottage industry character. The main goal of the current paper is to assess the potential of the Romanian silk value chain trough the point of view given by the value chain analysis perspective. Main elements used in the current research are represented by the comparative analysis of the values of imports, exports, trade balance and national production of silk and silk derived products in the following period of 20012018. The study will help highlight the potential for development within the sericulture national value chain highlighting the entry points in the value chain and identifying new internal and external markets.
\end{abstract}

Keywords: import, export, trade, silk, sericulture

\section{Introduction}

Sericulture, science that includes both silkworm rearing and silk processing into derived products, is an industry that is widely spread, worldwide, being present in over 60 countries, as it is considered being a lucrative industry with high employment potential (Mărghitaș et al., 2013; Popescu A, 2013; Popescu A, 2018).Silk is a sought-after material due to its elegance, delicacy and ecological nature. The origin of these textile fibers is the silk cocoon, which is produced largely by the Bombyx mori $L$ silkworm, also known as the mulberry silkworm, and it is widely used in complex fields, from textile industry, medicine and computer science (Furdui et al., 2010; Popescu, 2013).
Therefore the demand for silk is always present on the market, but the possibilities to fulfill the existing demand is constantly affected by different barriers, at productive or economic competitiveness level, such as low cost production of synthetic fibers and low cost natural fibers (such as cotton), production of low-cost silk and silk derived products imports at low levels (from countries such as China, India or Thailand) as well as the migration of the workforce towards other fields (Pașca et al., 2008; Popescu, A, 2013; Akram, 2015; Popescu., A, 2018).

The production of silk, from a value chain approach, follows certain sectors: input sector (silkworm egg production and mulberry plantations), cocoon production (farm level agricultural activi- 
ties), cocoon processing (into raw silk), spinning and twisting (silk yarn) and silk weaving (the production of silk textiles). In the case or Romania, the silk industry began to rapidly decline after especially after 1989 , as political regimes changed and state owned facilities became private, mulberry plantations have been in decline, the Logoj reeling facility closed and the support system for the silk industry began to decline as well. Losing its input sector, Silk industry in Romania, currently, is mainly focused on production of silk yarn and silk textiles, in complete dependence of foreign inputs (Pop et al., 2018).

The negative effects of the mentioned events affect the sericulture European industry as well as, due to low cost imports, European countries focus more on processing sector of the sericulture value chain. Therefore, the demand for raw inputs is covered by low cost imports mainly from countries like China or India, leaving opportunities for developing countries to relaunch the silk industry and enter the local market to gradually replace the raw material imports, a trend that Romania follows as well (Daltaet et al., 2005; Dezmirean et al, 2008; Kipriotes, 2008; Pasca et al.., 2008, Popescu, 2013; Mărghitaș et al., 2013).

The main goal of this article is to analyze, in more depth, the trade from the sericulture industry, focusing on, at a national level, on imports, exports and trade balance, as to identify the main sectors where local production can gradually replace imported inputs.

\section{Materials and methods}

The analyzed raw silk and silk derived products will be identified using NACE/CAEN codes, used in classification and identification of economic activities at national level or international levels. The used classification corresponds between the National (Romanian) Institute of Statistics and the statistics system of International Trade Center, aspect that is facilitating data correlation in present analysis.

The following categories of silk and silk derived products are analyzed: silkworm cocoons suitable for reeling (5001); raw silk "non-thrown"(5002); silk waste, including unsuitable cocoons for reeling, yarn waste and garneted stock(5003); silk yarn (excluding that spun from silk waste and that put up for retail sale)(5004); yarn spun from silk waste (excluding that put up for retail sale; (5005); silk yarn and yarn spun from silk waste, put up for retail sale(5006); silkworm gut and woven fabrics of silk or silk waste(5007). The analyzed data was compiled from two main sources, as the differences in declared data are insignificant: Eurostat and ITC (International Trade Center). The sectors of imports, exports and trade within the silk and silk derived products trade were analyzed, using a series of selected indicators. Analysis of the share of silk derived products within the total silk trade after the following formula: $\mathrm{S}=(\mathrm{Vp} / \mathrm{Vt}) * 100$

Analysis of the Compound Average Growth Rate (CAGR), indicator that, in the case of volatile data, is considered to be a representative figure to show the smoothed growth evolution during a certain given-time frame:

$\mathrm{CAGR}=\left((\mathrm{EV} / \mathrm{IV})^{*} 1 / \mathrm{T}\right)-1$ where $\mathrm{EV}=$ Ending value, $\mathrm{IV}=$ initial value, $\mathrm{T}=$ number of periods (Investopedia, 2019). For the studied silk derived product categories, the timeframe for analysis is calculated from the first point (from the year import has began).

Net Export Index is often used to analyze the trade of a certain sector or a country within a certain trade sector, as it takes into account the both evolution of import and export, with regard to its impact on production. Its applicability ranges from analysis of economic sector to analysis of trade of specific formulas. Its values are set between -1 (country is a net importer) and +1 (country is a net exporter). The calculation formula is as follows:

NEI = Xij-Mij/ Xij+Mij, where Xij represents the total exports of product (i) from country (j) and Mij total imports of product (i) from country (j).

The use of the Net Export Index is preferred over the Export index as it is considered more effective as it takes into account the relation between exports and imports rather than the sector of exports alone. (Rytko, 2014). 
Table. 1. Evolution of Romania's Import of Silk and silk derived products from the World

\begin{tabular}{|c|c|c|c|c|c|c|c|c|}
\hline $\begin{array}{l}\text { Category/ } \\
\text { Code }\end{array}$ & $\begin{array}{l}\text { Silkworm } \\
\text { cocoons } \\
\text { suitable for } \\
\text { reeling/ } \\
5001\end{array}$ & $\begin{array}{c}\text { Raw silk } \\
\text { "non- } \\
\text { thrown"/ } \\
5002\end{array}$ & $\begin{array}{l}\text { Silk waste, } \\
\text { including } \\
\text { unsuitable } \\
\text { cocoons for } \\
\text { reeling, yarn } \\
\text { waste and } \\
\text { garneted } \\
\text { stock/ } \\
5003\end{array}$ & $\begin{array}{l}\text { Silk yarn } \\
\text { (excluding } \\
\text { that spun } \\
\text { from silk } \\
\text { waste and } \\
\text { that put up } \\
\text { for retail } \\
\text { sale)/ } \\
5004\end{array}$ & $\begin{array}{l}\text { Yarn spun } \\
\text { from silk } \\
\text { waste } \\
\text { (excluding } \\
\text { that put up } \\
\text { for retail } \\
\text { sale/ } \\
5005\end{array}$ & $\begin{array}{l}\text { Silk yarn } \\
\text { and yarn } \\
\text { spun from } \\
\text { silk waste, } \\
\text { put up for } \\
\text { retail sale/ } \\
5006\end{array}$ & $\begin{array}{l}\text { Silkworm } \\
\text { gut and } \\
\text { woven } \\
\text { fabrics of } \\
\text { silk or silk } \\
\text { waste/ } \\
5007\end{array}$ & Total \\
\hline Year & \multicolumn{8}{|c|}{ Thousand Euro } \\
\hline 2001 & 1 & 2786 & 0 & 36 & 0 & 17 & 3103 & 5943 \\
\hline 2002 & 0 & 9357 & 0 & 20 & 0 & 32 & 4193 & 13602 \\
\hline 2003 & 0 & 6776 & 0 & 819 & 1 & 34 & 5785 & 13415 \\
\hline 2004 & 0 & 12067 & 23 & 3993 & 1 & 55 & 9135 & 25274 \\
\hline 2005 & 1 & 19212 & 4 & 5645 & 12 & 58 & 12868 & 37800 \\
\hline 2006 & 0 & 32875 & 14 & 7673 & 14 & 60 & 12194 & 52830 \\
\hline 2007 & 3 & 29562 & 53 & 9911 & 107 & 73 & 16981 & 56690 \\
\hline 2008 & 0 & 36950 & 70 & 9567 & 39 & 66 & 16165 & 62857 \\
\hline 2009 & 0 & 13095 & 187 & 3851 & 62 & 44 & 13351 & 30590 \\
\hline 2010 & 1 & 24508 & 277 & 4039 & 239 & 38 & 14461 & 43563 \\
\hline 2011 & 0 & 42517 & 241 & 4993 & 266 & 29 & 18545 & 66591 \\
\hline 2012 & 0 & 39980 & 22 & 5918 & 299 & 116 & 19569 & 65904 \\
\hline 2013 & 2 & 64770 & 49 & 6195 & 436 & 83 & 19140 & 90675 \\
\hline 2014 & 20 & 55512 & 110 & 6781 & 427 & 35 & 17825 & 80710 \\
\hline 2015 & 0 & 59111 & 160 & 6197 & 1366 & 23 & 16487 & 83344 \\
\hline 2016 & 7 & 76632 & 123 & 5660 & 950 & 48 & 19127 & 102547 \\
\hline 2017 & 0 & 54996 & 22 & 6642 & 1460 & 78 & 16812 & 80010 \\
\hline 2018 & 0 & 88200 & 26 & 6337 & 1028 & 115 & 17055 & 112761 \\
\hline CAGR & $-100.00 \%$ & $21.16 \%$ & $0.82 \%$ & $33.28 \%$ & $54.26 \%$ & $11.21 \%$ & $9.93 \%$ & $17.76 \%$ \\
\hline
\end{tabular}

Source: Data adaptation and calculation from ITC

\section{Results and discussions}

European and worldwide context, it can be stated that Romania, following the trend of many other European countries has turned from a silk cocoon and raw silk exporter to a raw silk importer and producer of textile fibers and producer of textiles and finished garments. At a European level, it can be stated, based on analyzed data and other studies that the silk industry in Romania, focuses mostly on finished textiles and garments, rather than the production of yarn as main processors of this material are represented by, et European level, by France and Italy, possible trade competitors but potentials markets as well (Popescu, 2013). Taking into account the open sectors where raw materials is completely provided by inputs, and also movements to implement sericulture in Eastern European countries once again, the current study undertakes to underline the sectors where the imports can be substituted with exports. The first sector to be analyzed is the imports flowing from the world towards Romania.

The Total Column represents the total silk trade value afferent to each year and its value is constant, therefore CAGR is not calculated. The total silk import value ranges between 5943 thousand Euro in 2001 and 112761 thousand Euro in 2018, with a compound average growth rate of $17.76 \%$. China, Italia, Germany, France, Austria, Belgium, Spain and India represent its 


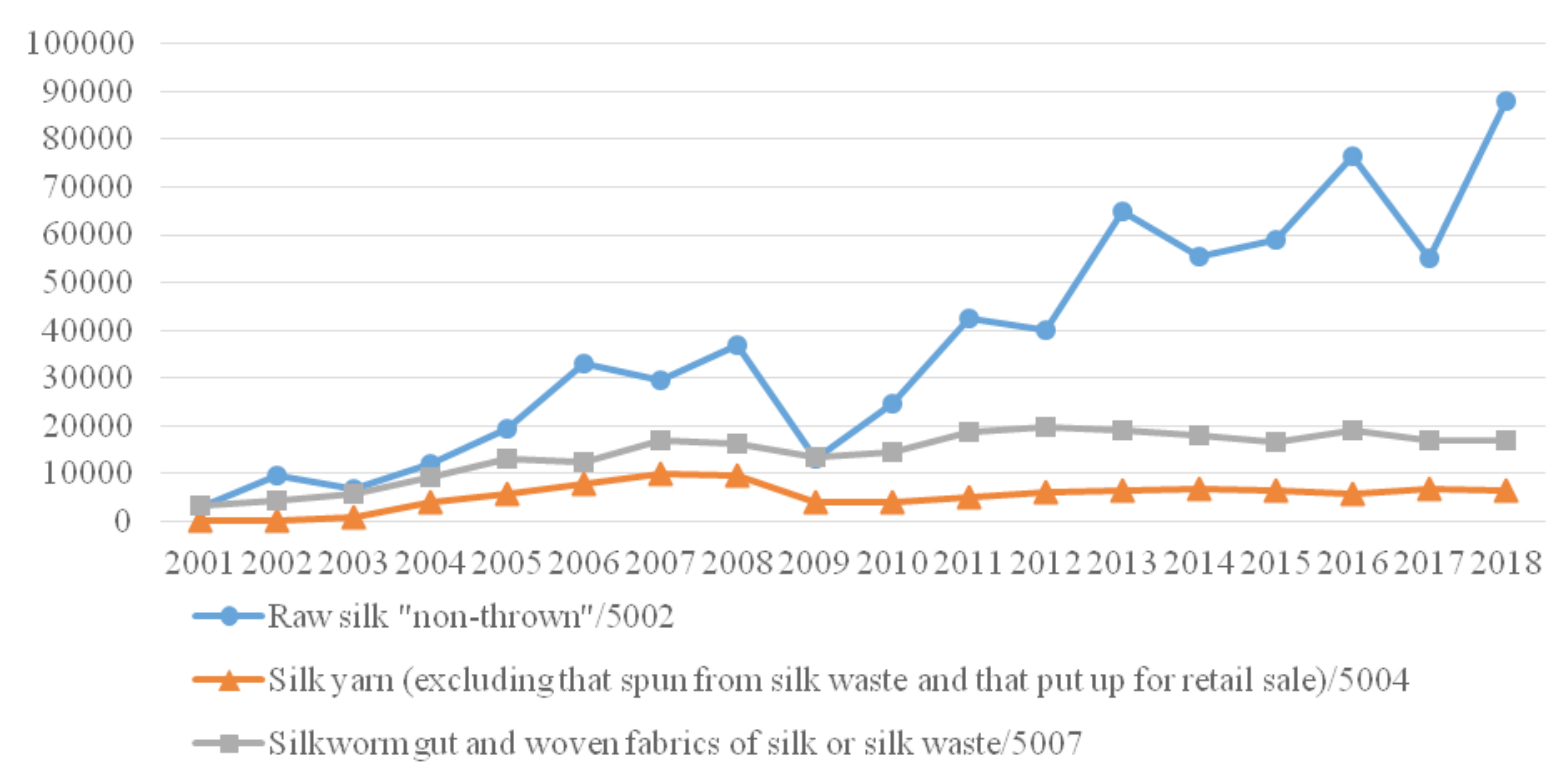

Figure 1. Main Silk Derived Products - Import Evolution (thousand Euro)

Table. 2. Structure of Silk and silk derived products imports within Romania

\begin{tabular}{ccccccccc}
\hline Code & 5001 & 5002 & 5003 & 5004 & 5005 & 5006 & 5007 & Total \\
\hline Year & & & \multicolumn{7}{c}{ Percentage $(\%)$} \\
\hline 2001 & 1.68 & 46.88 & 0.00 & 0.61 & 0.00 & 0.29 & 52.22 & 100.00 \\
\hline 2002 & 0.00 & 68.79 & 0.00 & 0.15 & 0.00 & 0.24 & 30.83 & 100.00 \\
\hline 2003 & 0.00 & 50.51 & 0.00 & 6.10 & 0.01 & 0.25 & 43.12 & 100.00 \\
\hline 2004 & 0.00 & 47.75 & 0.09 & 15.80 & 0.00 & 0.22 & 36.14 & 100.00 \\
\hline 2005 & 0.26 & 50.83 & 0.01 & 14.93 & 0.03 & 0.15 & 34.04 & 100.00 \\
\hline 2006 & 0.00 & 62.23 & 0.03 & 14.52 & 0.03 & 0.11 & 23.08 & 100.00 \\
\hline 2007 & 0.53 & 52.15 & 0.09 & 17.48 & 0.19 & 0.13 & 29.95 & 100.00 \\
\hline 2008 & 0.00 & 58.78 & 0.11 & 15.22 & 0.06 & 0.10 & 25.72 & 100.00 \\
\hline 2009 & 0.00 & 42.81 & 0.61 & 12.59 & 0.20 & 0.14 & 43.65 & 100.00 \\
\hline 2010 & 0.23 & 56.26 & 0.64 & 9.27 & 0.55 & 0.09 & 33.20 & 100.00 \\
\hline 2011 & 0.00 & 63.85 & 0.36 & 7.50 & 0.40 & 0.04 & 27.85 & 100.00 \\
\hline 2012 & 0.00 & 60.66 & 0.03 & 8.98 & 0.45 & 0.18 & 29.69 & 100.00 \\
\hline 2013 & 0.22 & 71.43 & 0.05 & 6.83 & 0.48 & 0.09 & 21.11 & 100.00 \\
\hline 2014 & 2.48 & 68.78 & 0.14 & 8.40 & 0.53 & 0.04 & 22.09 & 100.00 \\
\hline 2015 & 0.00 & 70.92 & 0.19 & 7.44 & 1.64 & 0.03 & 19.78 & 100.00 \\
\hline 2016 & 0.68 & 74.73 & 0.12 & 5.52 & 0.93 & 0.05 & 18.65 & 100.00 \\
\hline 2017 & 0.00 & 68.74 & 0.03 & 8.30 & 1.82 & 0.10 & 21.01 & 100.00 \\
\hline 2018 & 0.00 & 78.22 & 0.02 & 5.62 & 0.91 & 0.10 & 15.12 & 100.00 \\
\hline CAGR & -100.00 & 2.89 & -8.75 & 13.17 & 37.77 & -5.57 & -6.65 & \\
\hline & & & & & & & &
\end{tabular}

Source: Data adaptation and calculation from ITC

main sources for import, worldwide, as they detain the highest values of silk and silk derived products derived traded towards Romania.
According to the data from the Table 1 and 2 , it can be stated that the main imported group of products is represented by raw silk (5002, 
Table. 3. Evolution of Romania's Export of Silk and silk derived products to the World

\begin{tabular}{ccccccccc}
\hline Code & 5001 & 5002 & 5003 & 5004 & 5005 & 5006 & 5007 & Total \\
\hline Year & \multicolumn{7}{c}{ Thousand Euro } \\
\hline 2001 & 0 & 26 & 0 & 2826 & 0 & 0 & 226 & 3078 \\
\hline 2002 & 0 & 194 & 0 & 5472 & 0 & 0 & 691 & 6357 \\
\hline 2003 & 0 & 3141 & 0 & 5982 & 0 & 0 & 1440 & 10563 \\
\hline 2004 & 0 & 6990 & 0 & 6210 & 0 & 0 & 5016 & 18216 \\
\hline 2005 & 0 & 9384 & 3 & 9478 & 2 & 0 & 7824 & 26691 \\
\hline 2006 & 0 & 6775 & 0 & 24794 & 0 & 2 & 11246 & 42817 \\
\hline 2007 & 0 & 3801 & 0 & 29344 & 0 & 0 & 12706 & 45851 \\
\hline 2008 & 0 & 5780 & 0 & 32324 & 27 & 10 & 12653 & 50794 \\
\hline 2009 & 0 & 2176 & 8 & 22620 & 3 & 1 & 5600 & 30408 \\
\hline 2010 & 0 & 2945 & 23 & 26572 & 258 & 8 & 5558 & 35364 \\
\hline 2011 & 0 & 5553 & 47 & 37750 & 22 & 9 & 7419 & 50800 \\
\hline 2012 & 0 & 4360 & 1 & 44779 & 4 & 9 & 10562 & 59715 \\
\hline 2013 & 0 & 5717 & 0 & 51835 & 38 & 3 & 10957 & 68550 \\
\hline 2014 & 0 & 7911 & 1 & 54602 & 17 & 11 & 13402 & 75944 \\
\hline 2015 & 0 & 7533 & 0 & 59637 & 855 & 4 & 11811 & 79840 \\
\hline 2016 & 0 & 6453 & 5 & 57830 & 416 & 0 & 11567 & 76271 \\
\hline 2017 & 0 & 8210 & 0 & 64884 & 853 & 0 & 10211 & 84158 \\
\hline 2018 & 0 & 8520 & 0 & 66606 & 74 & 2 & 14293 & 89495 \\
\hline CAGR & $0.00 \%$ & $38.08 \%$ & $0.00 \%$ & $19.19 \%$ & $29.42 \%$ & $0.00 \%$ & $25.91 \%$ & $20.59 \%$ \\
\hline & & & & & & & &
\end{tabular}

Source: Data adaptation and calculation from ITC

fig. 1), ranging between 2767 thousand euro in 2001 and 88238 thousand euro in 2018, with a CAGR of $21.16 \%$. Its main imported partners are represented by China, Italy and Germany, according to the data provided by International Trade Center. In terms of its share in the total silk trade, in can be observed that it grows from $46.88 \%$ in 2001 to $78.22 \%$ in 2018 , with an average increase rate of $2.89 \%$, becoming most imported commodity within the import aspect of the silk trade. This is mainly due to the fact that Romanian Silk Industry is mostly focused on raw silk processing (as it can be seen also in Table 7) into yarn and silk derived textiles.

The second place is taken by group products named woven silk fabrics (5007, fig. 1) with its imported values ranging between 3103 thousand euro in 2001 to 17055 thousand Euro in 2018, registering a compound growth value of $9.93 \%$, as its upward trend is rather stable. Italy, Germany and France represent the main import markets. In terms of import market share, the value decreases from $52,22 \%$ in 2001 to $15.12 \%$ in 2018 , with a compound decrease rate of $6.65 \%$.

Silk yarn, excluding that spun from silk waste and that put up for retail sale (5004, fig. 1 ) is the group of products that occupies the third place. In 2001 , the imported value was of 36 thousand euro and increased, with an average rate of $33.28 \%$, to 6337 thousand euro in 2018. The main trade partners are represented by, mainly, Belgium and Italy. In terms of percentage evolution within the imported Romanian silk trade, its share ranges between $0.61 \%$ in 2001 , jumps to $17.48 \%$ in 2007 and then decreases to $5.62 \%$ in 2018 , registering an average growth rate of $13.17 \%$.

On the forth place is the category of silk products represented by Yarn spun from silk waste, excluding that put up for retail sale (5005), whose values of imports, although under ascending trend, have reduced values compared to the other categories of products derived from silk analyzed, namely from a value of 1 thousand euros in 2004 to a value of 1028 thousand euros in 2018, 


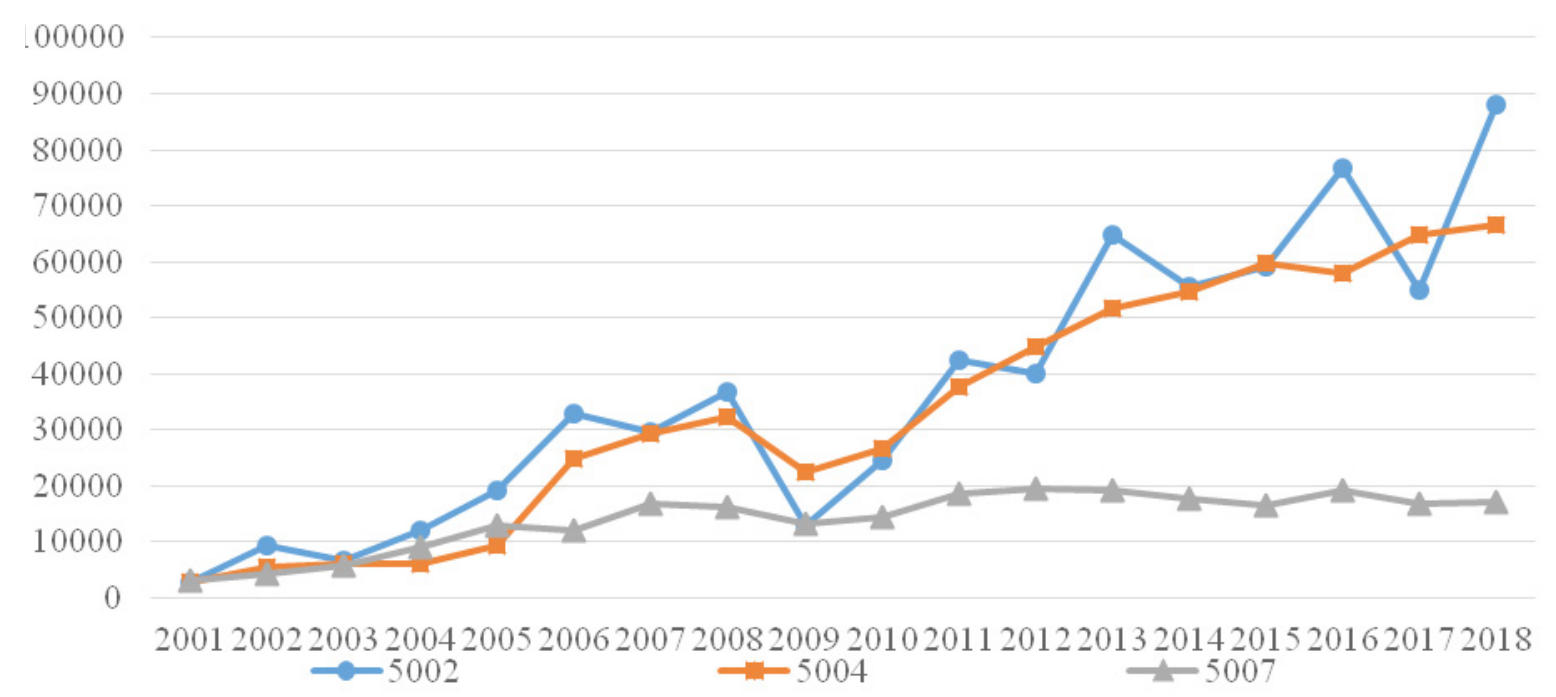

Figure 2. Main Silk Derived Products - Export Evolution (thousand Euro)

with a growth rate $54.26 \%$. The high value of the grow rate is mainly caused by a sudden increase in imports after 2007. The main exporting countries to Romania are represented by Italy and Germany. In terms of share within import, it can be stated that it decreases from $0.29 \%$ in 2001 to $0.10 \%$ in 2018 , with an average increase rate of $35.04 \%$.

In fifth place is the product category Silk yarn and yarn say from silk waste, put up for retail; silkworm gut (5006), where the value of imports increases from 17 thousand euros in 2001 to 115 thousand euros in 2018. Analyzing the reference period, the observed growth rate has a value of $11.21 \%$. Italy and Germany are the main exporters to Romania. In terms of percentages, in can be observed that this group of products is, in terms of import share, is decreasing with an average rate of $5.57 \%$, from $0.29 \%$ in 2001 to $0.10 \%$ in 2018 .

On the sixth place is the category of silk products represented by Silk waste, including cocoons unsuitable for reeling, yarn waste and garneted stock (5002), where the first import takes place in 2004, worth 23 thousand euros, and, in 2018 , it has an import value of 26 thousand euros. In the period studied, 2001-2018, an afferent growth rate of $0.82 \%$ has been registered. Imports are mainly provided by Italy and Germany. Its share within the import sector has declined from $0.09 \%$ in 2004 to $0.02 \%$ in 2018 , with an average rate of $6.65 \%$.
On the seventh place is the product group named Silkworm cocoons suitable for reeling (5001). Imports within the same category are relatively low, and towards the end of the period analyzed, the volume of silk donut imports decreased to 0 , one of the reasons being the absence of reeling facilities.The next stages of the market analysis are represented by export of silk and silk derived products analysis, followed by trade balance analysis.

The Total Column represents the total silk trade value afferent to each year and its value is constant, therefore CAGR is not calculated.

The aggregate silk export value ranges between 3078 in 2001 and 89495 in 2018, with a compound average growth rate of $20.59 \%$. Main markets where Romania exports silk to are represented by Italy, Hungary, United Kingdom, France, Germany, Switzerland and Bulgaria, focusing its external trade, mainly within and around European Union Region.

In terms of exports, according to the results presented in the tables 3 and 4 , it can be stated that on the first place, from within the silk and silk derived products, are the product groups represented by Silk yarn (fig.2), excluding that spun from silk waste and that put up for retail sale (5004), with its exported afferent values ranging from 2826 thousand euro in 2001 to 66606 thousand euro in 2018, registering a compound average growth rate of $29.42 \%$. In terms of export 
Table. 4. Structure of Silk and silk derived products exports from Romania

\begin{tabular}{ccccccccc}
\hline Code & 5001 & 5002 & 5003 & 5004 & 5005 & 5006 & 5007 & Total \\
\hline Year & & & \multicolumn{7}{c}{ Percentage (\%) } & & & \\
\hline 2001 & 0.00 & 0.83 & 0.00 & 91.82 & 0.00 & 0.00 & 7.34 & 100.00 \\
\hline 2002 & 0.00 & 3.05 & 0.00 & 86.08 & 0.00 & 0.00 & 10.87 & 100.00 \\
\hline 2003 & 0.00 & 29.74 & 0.00 & 56.63 & 0.00 & 0.00 & 13.63 & 100.00 \\
\hline 2004 & 0.00 & 38.37 & 0.00 & 34.09 & 0.00 & 0.00 & 27.54 & 100.00 \\
\hline 2005 & 0.00 & 35.16 & 0.01 & 35.51 & 0.01 & 0.00 & 29.31 & 100.00 \\
\hline 2006 & 0.00 & 15.82 & 0.00 & 57.91 & 0.00 & 0.00 & 26.27 & 100.00 \\
\hline 2007 & 0.00 & 8.29 & 0.00 & 64.00 & 0.00 & 0.00 & 27.71 & 100.00 \\
\hline 2008 & 0.00 & 11.38 & 0.00 & 63.64 & 0.05 & 0.02 & 24.91 & 100.00 \\
\hline 2009 & 0.00 & 7.16 & 0.03 & 74.39 & 0.01 & 0.00 & 18.42 & 100.00 \\
\hline 2010 & 0.00 & 8.33 & 0.07 & 75.14 & 0.73 & 0.02 & 15.72 & 100.00 \\
\hline 2011 & 0.00 & 10.93 & 0.09 & 74.31 & 0.04 & 0.02 & 14.60 & 100.00 \\
\hline 2012 & 0.00 & 7.30 & 0.00 & 74.99 & 0.01 & 0.02 & 17.69 & 100.00 \\
\hline 2013 & 0.00 & 8.34 & 0.00 & 75.62 & 0.06 & 0.00 & 15.98 & 100.00 \\
\hline 2014 & 0.00 & 10.42 & 0.00 & 71.90 & 0.02 & 0.01 & 17.65 & 100.00 \\
\hline 2015 & 0.00 & 9.43 & 0.00 & 74.70 & 1.07 & 0.01 & 14.79 & 100.00 \\
\hline 2016 & 0.00 & 8.46 & 0.01 & 75.82 & 0.55 & 0.00 & 15.17 & 100.00 \\
\hline 2017 & 0.00 & 9.76 & 0.00 & 77.10 & 1.01 & 0.00 & 12.13 & 100.00 \\
\hline 2018 & 0.00 & 9.52 & 0.00 & 74.42 & 0.08 & 0.00 & 15.97 & 100.00 \\
\hline CAGR & 0.00 & 14.50 & 0.00 & -1.16 & 18.71 & -5.96 & 4.41 & \\
\hline
\end{tabular}

Source: own calculation

trade percentage within the silk aggregate value, it can be stated that its share decreases from $91.82 \%$ in 2001 to $74.42 \%$ in 2018 , decreasing, on average, with $1.16 \%$ within the studied timeframe. In terms of trade partners, Romania exports silk yarn mainly towards Italy, Belgium, Austria and Bulgaria.

Woven fabrics of silk or of silk waste (5007) product group(fig.2) occupies the second place. The total exported values increases from 226 thousand euro in 2001 to 14293 thousand euro in 2018, at an average (compound) growth rate of $25.91 \%$. In terms of export trade share within the silk aggregate group, its values increases (with a fluctuant trend) from $7.34 \%$ in 2001 to $15.97 \%$ in 2018 , registering a compound average compound growth rate of $4.41 \%$. In the case of this subcategory of silk derived products, in terms of exports, Italy, Germany, France and China represent main trade partners.

Raw silk "non-thrown" (5002) silk product group (fig.2) is situated on the third place, with afferent exported values growing, with a compound average rate of $38.08 \%$, from 26 thousand euro(0.83\%) in 2001 to 8520 thousand euro in $2018(9.52 \%)$. Its main trade partners, in terms of export, are represented by China and Italy. As Romania has a lower silk processing capacity, due to silk value chain infrastructure decline, some of exports are destined towards exports.

On the fourth place, is the product group represented by Yarn spun from silk waste, excluding that put up for retail sale (5005). The exported values range from 2 thousand euro in 2005 to 853 thousand euro in 2017 (trend peak), then decrease to 74 thousand euro in 2018. The compound average growth rate for the selected period registers the value of $29.42 \%$. In terms of trade percentage, its share are quite low, ranging from $0.01 \%$ in 2005 to 0.08 in 2018 , at a compound average growth rate of $18.71 \%$. Main markets towards where this group of products is exported to are represented by Italy and Germany. 
Table. 5. Silk and silk derived products Romanian Trade Balance

\begin{tabular}{lcccccccc}
\hline Code & 5001 & 5002 & 5003 & 5004 & 5005 & 5006 & 5007 & Total \\
\hline Year & \multicolumn{7}{c}{ Thousand Euro } \\
\hline 2001 & -1 & -2760 & 0 & 2790 & 0 & -17 & -2877 & -2864 \\
\hline 2002 & 0 & -9163 & 0 & 5452 & 0 & -32 & -3502 & -7245 \\
\hline 2003 & 0 & -3635 & 0 & 5163 & -1 & -34 & -4345 & -2852 \\
\hline 2004 & 0 & -5077 & -23 & 2217 & -1 & -55 & -4119 & -7058 \\
\hline 2005 & -1 & -9829 & -1 & 3833 & -10 & -58 & -5044 & -11109 \\
\hline 2006 & 0 & -26100 & -14 & 17121 & -14 & -58 & -948 & -10013 \\
\hline 2008 & -3 & -25761 & -53 & 19433 & -107 & -73 & -4275 & -10836 \\
\hline 2009 & 0 & -31171 & -70 & 22757 & -12 & -56 & -3512 & -12064 \\
\hline 2010 & -1 & -21563 & -254 & 22533 & 19 & -30 & -8903 & -8198 \\
\hline 2011 & 0 & -36964 & -194 & 32757 & -244 & -20 & -11126 & -15791 \\
\hline 2012 & 0 & -35620 & -21 & 38861 & -295 & -107 & -9007 & -6189 \\
\hline 2013 & -2 & -59053 & -49 & 45640 & -398 & -80 & -8183 & -22123 \\
\hline 2014 & -20 & -47601 & -109 & 47821 & -410 & -24 & -17825 & -18148 \\
\hline 2015 & 0 & -51579 & -160 & 53440 & -511 & -19 & -4676 & -3505 \\
\hline 2016 & -7 & -70179 & -118 & 52170 & -534 & -48 & -7560 & -26269 \\
\hline 2017 & 0 & -46786 & -22 & 58242 & -607 & -78 & -6601 & 4148 \\
\hline 2018 & 0 & -79680 & -26 & 60269 & -954 & -113 & -2762 & -23266 \\
\hline CAGR & $-100.00 \%$ & $20.54 \%$ & $0.82 \%$ & $18.61 \%$ & $53.54 \%$ & $11.10 \%$ & $-0.23 \%$ & $12.34 \%$ \\
\hline & & -10919 & -179 & 18769 & -59 & -43 & -7751 & -182 \\
\hline
\end{tabular}

Source: Data adaptation and calculation from ITC

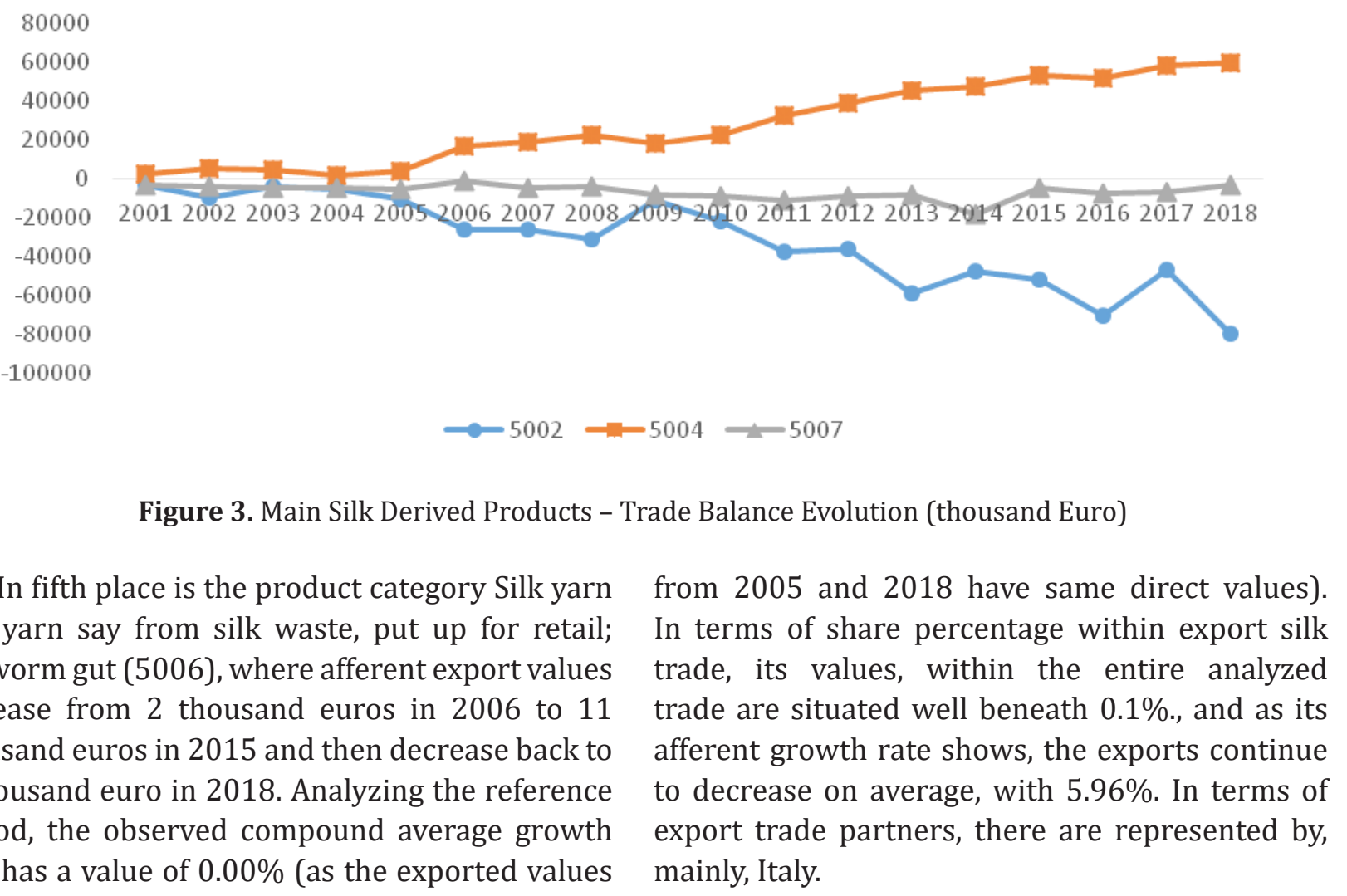


Table. 6. Net Exporter Index. Romanian Silk trade

\begin{tabular}{ccccccccc}
\hline Code/Year & 5001 & 5002 & 5003 & 5004 & 5005 & 5006 & 5007 & Total \\
\hline 2001 & -1.00 & -0.98 & 0.00 & 0.97 & 0.00 & -1.00 & -0.86 & -0.32 \\
\hline 2002 & 0.00 & -0.96 & 0.00 & 0.99 & 0.00 & -1.00 & -0.72 & -0.36 \\
\hline 2003 & 0.00 & -0.37 & 0.00 & 0.76 & -1.00 & -1.00 & -0.60 & -0.12 \\
\hline 2004 & 0.00 & -0.27 & -1.00 & 0.22 & -1.00 & -1.00 & -0.29 & -0.16 \\
\hline 2005 & -1.00 & -0.34 & -0.14 & 0.25 & -0.71 & -1.00 & -0.24 & -0.17 \\
\hline 2006 & 0.00 & -0.66 & -1.00 & 0.53 & -1.00 & -0.94 & -0.04 & -0.10 \\
\hline 2007 & -1.00 & -0.77 & -1.00 & 0.50 & -1.00 & -1.00 & -0.14 & -0.11 \\
\hline 2008 & 0.00 & -0.73 & -1.00 & 0.54 & -0.18 & -0.74 & -0.12 & -0.11 \\
\hline 2009 & 0.00 & -0.71 & -0.92 & 0.71 & -0.91 & -0.96 & -0.41 & 0.00 \\
\hline 2010 & -1.00 & -0.79 & -0.85 & 0.74 & 0.04 & -0.65 & -0.44 & -0.10 \\
\hline 2011 & 0.00 & -0.77 & -0.67 & 0.77 & -0.85 & -0.53 & -0.43 & -0.13 \\
\hline 2012 & 0.00 & -0.80 & -0.91 & 0.77 & -0.97 & -0.86 & -0.30 & -0.05 \\
\hline 2013 & -1.00 & -0.84 & -1.00 & 0.79 & -0.84 & -0.93 & -0.27 & -0.14 \\
\hline 2014 & -1.00 & -0.75 & -0.98 & 0.78 & -0.92 & -0.52 & -1.00 & -0.13 \\
\hline 2015 & 0.00 & -0.77 & -1.00 & 0.81 & -0.23 & -0.70 & -0.17 & -0.02 \\
\hline 2016 & -1.00 & -0.84 & -0.92 & 0.82 & -0.39 & -1.00 & -0.25 & -0.15 \\
\hline 2017 & 0.00 & -0.74 & -1.00 & 0.81 & -0.26 & -1.00 & -0.24 & 0.03 \\
\hline 2018 & 0.00 & -0.82 & -1.00 & 0.83 & -0.87 & -0.97 & -0.09 & -0.12 \\
\hline CAGR & $-100.00 \%$ & $-0.97 \%$ & $0.00 \%$ & $-0.91 \%$ & $-0.90 \%$ & $-0.19 \%$ & $-11.91 \%$ & $-5.49 \%$ \\
\hline
\end{tabular}

Source: own calculation

On the sixth place is the category of silk products represented by Silk waste, including cocoons unsuitable for reeling, yarn waste and garneted stock (5002), due to the fact that, in terms of export trade, this silk derived product is presented only 7 times within the studied time frame, as the exported values grow from 3 thousand euro in 2005 to 47 thousand in 2012, dropping back to 5 thousand euro in 2016. The compound average growth rate is $0.00 \%$ as the exports disappear completely in 2018. In terms of export trade share percentages, its values are situated, within every year of the selected period, well under $0.01 \%$. Main export trade partners are represented by Italy and Germany.

On the seventh place is the product group named Silkworm cocoons suitable for reeling (5001) as within the export sector, this group of products is completely absent.

In terms of the silk trade balance, its evolution can be observed within tables 5 and 6 .

When considering the analysis of compound average growth rate regarding the Trade Balance and Net Export Index, the calculation was implemented using the absolute value in order to properly highlight the growth of the trade surplus or deficit afferent to each silk derived product group. In terms of trade balance significance, if the results are negative, then within the trade there is a deficit within the availability of the analysed product/sector on the afferent market, but if the result is positive it can denote there is a surplus within production and local market, assuring the successful development of that industry.

According to tables 5 and 6 , it can be stated that the nature of the Romanian silk trade is rather dynamic, but mostly characterized by deficit in most of its silk and silk derived products, main exception being the trade sector of silk yarn, excluding that spun from silk waste and that put up for retail sale (5004).

From table 5 and 6, it can observed that the largest values in terms of trade deficit (lack of product on the market) is registered by raw silk product group (5002, fig. 3), as deficit grows with an average rate of $20.54 \%$, silk woven fabrics 
Table. 7. National Production - Silk and silk derived products

\begin{tabular}{|c|c|c|c|}
\hline Code & 5001 & 5004 & 5007 \\
\hline & \multicolumn{3}{|c|}{ Thousand Euro } \\
\hline 2001 & 4.20 & Confidential data & 19932 \\
\hline 2002 & 3.20 & Confidential data & 27202 \\
\hline 2003 & 8.70 & Confidential data & 20687 \\
\hline 2004 & 7.70 & Confidential data & 19116 \\
\hline 2005 & 13.70 & Confidential data & 0 \\
\hline 2006 & 5.20 & Confidential data & 23029 \\
\hline 2007 & 3.60 & Confidential data & 29579 \\
\hline 2008 & 23.00 & Confidential data & 25448 \\
\hline 2009 & 18.10 & Confidential data & 14475 \\
\hline 2010 & 0 & Confidential data & 16727 \\
\hline 2011 & 0 & 35192 & 17635 \\
\hline 2012 & 0 & Confidential data & 22418 \\
\hline 2013 & 0 & Confidential data & 26353 \\
\hline 2014 & 0 & 57968 & 26493 \\
\hline 2015 & 0 & Confidential data & 24470 \\
\hline 2016 & 0 & 56450 & 24708 \\
\hline 2017 & 0 & 67236 & 22729 \\
\hline 2018 & 0 & 67687 & 24064 \\
\hline CAGR & $-100 \%$ & $12 \%$ & $1 \%$ \\
\hline
\end{tabular}

Source: Data adaptation from Eurostat (PRODCOM database)

(5007, fig. 3), as it afferent deficit decreases slowly with a rate of $0.23 \%$. The silk yarrn product group (5004, fig. 3) is positive in value with average growth rate of $18.61 \%$, as exports exceed imports. As seen from the trade balance values, the above mentioned represent the sectors with the highest level of trade activity.

Concerning the NEI Index, as presented in table 6, regarding the following silk silk derived products: raw silk "non-thrown"(5002); yarn spun from silk waste (excluding that put up for retail sale; (5005); silk yarn and yarn spun from silk waste, put up for retail sale(5006); silk waste, including unsuitable cocoons for reeling, yarn waste and garneted stock(5003); and silkworm cocoons suitable for reeling (5001), Romania is a net Importer as the values or the Index are close to -1 , meaning the trade activity leans towards imports. The category of woven fabrics (5007) has its NEI index closer to value of ), meaning aferent trade, supported by local production, is gaining capacity to satisfy local demand and forward increase value trade tough exports.

Concerning silk yarn, excluding that spun from silk waste and that put up for retail sale, as the trade balance shows surplus on the local market, NEI Index registers values closer to 1, as trade activity shows ability to satisfy local demand trough combined activity of imports and increasing local production.

The main significance of this aspect is that Romania is a netimporter in relation to the majority of raw silk and silk derived products. Therefore, it can be stated that these are the main groups of silk products demanded on the Romanian Silk Market, therefore the sectors afferent to the production of silk yarn and silk derived products represent 2 of the main entry points within the silk value chain as demand exists and competition is low or nonexistent, as proven by the volume of import and structure of national silk production

In terms of production, within the sericulture industry, within Romania, the production has 
shifted its focus only on the textile manufacture sector, as analyzed data from table 7 will show.

From the data presented in table 7 , the best evolution, in terms of production (value of production), was registered by Woven fabrics of silk or of silk waste silk (5007) product group, with a general upward trend, as the average compound growth rate shows with a positive value of $1 \%$. The value of production grows from 19932 thousand Euro in 2001 to 24064 thousand euro in 2018. Concerning silk yarn, excluding that spun from silk waste and that put up for retail sale (2004), from obtained data, it can be stated that local production is present, but statistical data availability is low. Therefore, it can be stated that the production value grows from 35192 thousand euro in 2011 to 67687 thousand euro in 2018, at an average rate of $12 \%$. Silkworm cocoons (5001) had their production stopped in 2009, as the last production value registered presents a sum of 18 thousand euro approximatively, as the agriculture infrastructure afferent to sericulture declines.

From what has been stated above it can be deduced that agricultural sector responsible for providing silkworm cocoons and the connection sector, meaning the filature, are missing from the silk value chain, remaining only the processing sector, meaning the production of silk yarn and silk textiles is still well developed and with a production, that, in terms of value, shows a growing trend. But the complete dependency of foreign raw material has also its risks, as the price movements directly affect the purchasing industry or country.

Therefore, a slow development of silk cocoon production sector and the manufacture of raw silk, slowly substituting the imports with local production can prove to be an opportune driver for the development of Romanian Sericulture as the manufacture sector is dependent on imports of raw silk. The potential identified entry points in the silk value chain can be in the production of silk cocoons and raw silk as these sectors are mainly satisfied by imports. Lack of production within this sectors shows that there is no internal competition within these silk value chain segments.

As previous studies in sericulture industry relaunch possibility state, one vital method is the launch or a coherent value chain with focus on connecting the broken existing segments from silk manufacturing industry and other organizations (with support functions in production modernization, legislation support, financial support etc). The current study proves there is demand for raw inputs such as silk cocoons and raw silk, therefore providing a secure market (Popescu et al, 2008), and, in the same time, opening an entry point in the silk value chain.

In terms of organization forms, for small farms (suitable for sericulture practice, as seasonal activity) it is more viable to enter as a silkworm rearer association (therefore production capacity can be increased and costs lowered). Silk cocoon reeling is a second entry point in the silk value chain, where actors can either join as new companies or existing companies (processors of raw silk, as their activity is proven by the presence of production of silk yarn from raw silk) can enter through expansion of their production line by adding a silk cocoon reeling unit.

\section{Conclusion}

Through the analysis of the imports sector of silk and silk derived products, it can be stated that one of the main imported categories is raw silk (5002), where demand on the Romanian Market is satisfied $100 \%$ trough imports. The other imported silk derived products group is represented by Woven fabrics of silk or of silk waste, used in production or destined for retail and re-export. The trends afferent to the mentioned subsectors have upward general trends. China, Italy, Germany, France and Belgium represent the main trade partners in the import sectors.

Analyzing the silk and silk derived product export sector, it is observed that the silk fabrics and the silk yarn group, followed by the raw silk, represent the main export groups, whose general trend is an ascending one. The export market is mainly focused on the European market, in countries such as Italy, France, Germany, Belgium and Bulgaria.

The only group of products derived from silk, where the surplus confirms the balance is that of silk yarns, the quantity imported, being doubled by the local production. 
At a national level, main silk derived products are represented by Silk yarn (excluding that spun from silk waste and that put up for retail sale (5004) and Woven fabrics of silk or of silk waste (5007), whose production value registers a growing trend, meaning that the silk derived products manufacture sector in Romania is still reasonable developed, denoting the aspect that investing in the development of the sector within sericulture responsible to provide the raw material for the silk textiles manufacture companies, raw materials such as raw silk and silk thread.

The sericulture industry in Romania owns still considerable potential, despite the fact that the manufacture sectors are dependent on importing raw materials such as raw silk, meaning that investments and development strategies should focus on developing the input sectors from the sericulture value chain, meaning the sectors responsible for the development of mulberry orchards, silkworm egg production and commercialization, silkworm cocoon production and raw silk production and marketing, as well as support services meant to connect the broken sectors of the silk value chain. This development direction can also lead to a secondary development benefit, meaning gaining the possibility to replace inputs with local production.

Acknowledgments. This research did not receive any specific grant from funding agencies in the public, commercial, or not-for-profit sectors.

\section{References}

1. Akram S (2015). Analysis of the Silk Value Chain in Pakistan. International Jurnal of Modern Trends in Engineering and Research (IJMTER), 02 (08): 223-236.

2. Dalta RK, Nanavaty M (2005). Global Silk Industry, a Complete Source Book. USA: Universal Publishing, (Chapter 1-3).

3. Dezmirean DS, Mărghitaș L Al (2008). Sericulture. Present and Future at the University of Agricultural Sciences and Veterinary Medicine, Cluj Napoca. Proceedings of The First International Conference „Sericulture - From Tradition to Modern Biotechnology". Cluj-Napoca: 7-10.

4. Furdui M E, Mărghitaș Al L, Dezmirean D, Mihai CM, Bobiș O, Pașca I (2010.) Comparative Study of Biological Characteristics of Larvae, Crude and Dried Cocoon in 7 Races of Silkworm Bombyx Mori L., Raised in Transylvania Area. Scientific Papers: Animal Sciences and Biotechnologies, 43 (1): 490-493.
5. Kipriotis E (2008). The silk product consumption in the European Union and the Sericulture's Future Potential. Proceedings of The First International Conference "Sericulture - From Tradition to Modern Biotechnology" Cluj-Napoca: 24-42.

6. Matei A, Popescu A, Dolis M, Tzenov PI, Bougiouskos K (2016). Research concerning the Natural Silk Market. Scientific Papers Series Animal Production, Iași, 49: 899905.

7. Mărghitaș L Al, Dezmirean DS (2013). Sericulture Status and Developing Strategies in Romania. Buletin USAVM Animal Sciences and Biotechnologies, 70 (1): 1-8.

8. Dezmirean D S, Pașca I, Morar R, Matei A, Mărghitaș L AL (2008). Sericicultură. Teoretică și practică. Cluj Napoca: Ed Riso-Print, (Chapter 1).

9. Pașca I, Șara A., Bențea M. Dezmirean D, Mărghitaș Al L (2009). Producția unor hibrizi de viermi de mătase ai dudului. Ed. Academic Press. Cluj Napoca: 15-16.

10. Pau E, Tănase DB (2006). Silk Handicraft Cottage Industries and Silk Industry Enterprises in Romania. In: International Workshop on Silk Handicrafts Cottage industries and Small Enterprises in Africa, Europe, Asia and Near East \& The Second Executive Meeting of The Black, Caspian Seas and Central Asia Silk Association (BACSA), Turkey: 175-195.

11. Pop LL, Mărghitaș Al L, Dezmirean D, Bobiș O, Moise A, Pașca C (2018). Sericiculture Industry In Romania - Analysis On Current Situation And Prospects Of Development. In: Scientific Papers. Series D. Animal Science, LXI (1): 251-258.

12. Popescu, A (2013). Trends in World Silk Cocoons and Silk Production and Trade, 2007-2010. Scientific Papers, Series Animal Science and Biotechnologies, 46 (2): 418423.

13. Popescu A (2018). Considerations Upon the Trends In the World Silk trade. Scientific Papers, Series Management, Economic Engineering and Rural Development, 18 (1): 385-400.

14. Rytko A (2014). Competitiveness of Polish and Slovak agrifood products on the European market. Polityki Europejskie, Finanse I Marketing, 12(61): 187-198.

15. Tzenov PI, Lece HZ (2006). Silk Handicraft Cottage Industries and Small Enterprises in Africa, Europe, Asia and Near East. International Workshop on Silk Handicrafts Cottage industries and Small Enterprises in Africa, Europe, Asia and Near East \& The Second Executive Meeting of The Black, Caspian Seas and Central Asia Silk Association (BACSA), Turkey: 17-71.

16. ITC (International Trade Center). Dataset: List of products imported by Romania, detailed products in the following category: 50 Silk. Url: https://www.trademap. org/Product_SelCountry_TS.aspx?nvpm $=1 \% 7 \mathrm{c} 642 \% 7 \mathrm{c} \%$ 7c\%7c\%7c50\%7c\%7c\%7c4\%7c1\%7c1\%7c1\%7c2\%7c1 \%7c1\%7c1\%7c1. Accesed: 29.09.2019.

17. ITC (International Trade Center). Dataset: List of products exported by Romania, detailed products in the 
following category: 50 Silk. Url: https://www.trademap. org/Product_SelCountry_TS.aspx?nvpm=1\%7c642\%7c\% 7c\%7c\%7c50\%7c\%7c\%7c4\%7c1\%7c1\%7c2\%7c2\%7c1 \%7c1\%7c1\%7c1. Accesed: 29.09.2019.

18. Eurostat. Dataset: Sold Production, exports and Imports by PRODCOM list (NACE rev. 2 - annual data (aact_eaa04).
URL: https://ec.europa.eu/eurostat/web/prodcom/ data/database. Accesed: 29.09.2019.

19. Eurostat. Dataset: Economic accounts for agriculture - values at real prices. URL: https://ec.europa.eu/ eurostat/web/products-datasets/-/aact_eaa04. Accesed: 29.09.2019. 